\title{
PENALARAN ILMIAH DALAM CIPTAAN-CIPTAAN BIONIK (BIONIC INVENTIONS)
}

\author{
Tomi Hidayat $^{1 *}$ dan Armansyah Putra ${ }^{2}$ \\ ${ }^{1}$ Program Studi Pendidikan Biologi, FKIP, Universitas Muhammadiyah Bengkulu \\ 2 Program Studi Pendidikan Biologi, FKIP, Universitas Samawa (UNSA) \\ *E-mail: tomihidayat@umb.ac.id
}

\begin{abstract}
Abstrak
Artikel ini membahas tentang penalaran ilmiah dalam hasil ciptaan Bionik. Proses penalaran ilmiah sebagai bagian dari kemampuan berpikir manusia dalam ciptaan-ciptaan Bionik (Bionic Inventions) yang diwujudkan pada penelitian-penelitian antara gabungan biologi dan elektronik. Bionik merupakan gabungan dari kata biologi dan elektronik, sistem mekanik makhluk hidup yang berfungsi seperti organ atau anggota tubuh makhluk hidup, mulai dari tangan, kaki, pendengaran, hingga penglihatan, semua bisa diperbaiki atau diganti (prosthesis) serta inspirasi teknologi pada semua makhluk hidup. Artikel secara rinci mengungkap konsep-konsep Bionik, ciptaan-ciptaan Bionik pada makhluk hidup (manusia, hewan dan tumbuhan), serta hubungan penalaran ilmiah dengan ciptaanciptaan Bionik (Bionic Inventions). Penciptaan Bionik termasuk dalam penalaran ilmiah induktif, deduktif dan abduktif yang berarti terdapat adanya proposisi hukum (rule), proposisi tentang suatu kasus (case), dan terakhir proposisi tentang kesimpulan (result) serta probabiltas yang tinggi yang terlepas dari falsifikasi (pseudo science). Bagian ini berisi intisari (abstrak) dari penelitian anda, Semua informasi tentang persyaratan dan format ada dalam template ini. Bacalah secara teliti dan mohon diperhatikan jangan mengubah format. Agar sama dengan format ini, Anda kami sarankan untuk melakukan copy bagain per bagian dari makalah yang sudah anda siapkan dan menempelkan/paste pada bagian template yang sesuai. Maksimum abstrak adalah 150 kata, dan maksimum halaman untuk setiap makalah adalah lima belas (15). Aturan penulisan pustaka mengacu pada gaya penulisan IEEE.
\end{abstract}

Kata kunci: Penalaran IImiah, Bionic Inventions, Induktif, Deduktif, Abduktif.

\section{PENDAHULUAN}

Hasil ciptaan teknologi saat sekarang ini merupakan salah satu dari perkembangan akal dan pikiran mausia sebagai makhluk yang paling sempurna dari makhluk hidup lainnya. Ciptaan dengan teknologi semakin maju membuat para ilmuwan semakin inovatif. Mereka tertantang untuk menciptakan alat-alat yang bisa menggantikan fungsi alat tubuh yang sudah rusak dan menggunakan media makhluk hidup sebagai penelitian, salah satunya dengan melakukan ciptaan-ciptaan Bionik. Banyak makhluk hidup (terutama manusia) di bumi ini yang telah merasakan menjadi hasil teknologi Bionik (Fell, 2007).

Bionik adalah sebuah istilah yang mengacu kepada aliran gagasan dari biologi sampai teknik dan sebaliknya (Juan dkk, 2014). Bionik, ilmu yang mempelajari penerapan metode biologis dan sistem yang ditemukan di alam untuk penelitian dan desain sistem rekayasa dan teknologi modern. Di bidang kedokteran, Bionik berarti pergantian atau perbaikan organ-organ atau bagian tubuh lainnya oleh versiversi mekanis. Penanaman bionik berbeda dengan bagian badan buatan belaka dengan meniru fungsi aslinya dengan sangat persis, atau bahkan mengunggulinya. Di bidang teknologi, Bionika mengacu kepada perkembangan teknologi-teknologi tertentu yang menduplikasikan adaptasi biologis terhadap lingkungan.

Di Indonesia sendiri Bionik dalam bidang kedokteran telah dikembangkan. Bionik adalah natur sains baru asli dari Indonesia, dibangun sejak 1974 dari riset (eksperimen) sehingga pengetahuan ini dilandaskan pada bukti yg didapat dari percobaan. Pengetahuan ini bertujuan untuk mempelajari semua fenomena metafisik (mistis, magis, supranatural, mukjizat) dengan pemikiran saintifik bukan dengan pemikiran mitologi maupun berdasarkan kepercayaan/religi tertentu. Ciptaan Bionik sebagai 
salah satu bukti bahwa manusia memiliki kelebihan yaitu memiliki akal dan pikiran yang berkembang.

Berpikir adalah keistimewaan yang hanya dimiliki oleh manusia yang tidak dimiliki oleh makhluk hidup lainnya. Berpikir adalah memanipulasi data, fakta dan informasi untuk membuat keputusan berperilaku (Dharma dalam Tawil, 2013: 1). Dalam proses berpikir manusia kadangkala tidak disertai dengan nalar yang baik. Dalam berpikir tidak selalu terkandung penalaran, tetapi dalam bernalar selalu terkandung proses berpikir (Suriasumantri, 2009).

Berpikir dengan penalaran ilmiah rasanya begitu mudah, setiap hari penalaran ilmiah digunakan, baik itu berbicara, berdialog, menulis, membaca uraian, mengkaji suatu tulisan, mendengarkan penjelasan, menarik kesimpulan dari apa yang dilihat dan didengar. Namun, apabila diselidiki lebih lanjut dan apabila harus dipraktekkan dengan sungguh-sungguh, ternyata penalaran ilmiah dengan teliti dan tepat merupakan kegiatan yang cukup sukar. Penalaran ilmiah ini sukar atau sulit karena sudah masuk bagian dari berpikir tingkat tinggi yang kompleks. Keterampilan penalaran adalah adanya korelasi antara kemampuan teoritis dan hirarki baru dari suatu konsep (Lawson, 2000). Proses keterampilan penalaran dengan menggunakan metode penalaran secara induktif, deduktif dan abduktif (Kuhn, 2000). Proses penalaran ilmiah dari masa ke masa mengalami perkembangan, seiring dengan kemajuan zaman di bidang ilmu pengetahuan dan teknologi (Laius, 2011. Penalaran ilmiah bisa dihubungkan dalam ciptaan-ciptaan Bionik terutama dalam bidang sains, hubungan tersebut dengan pengambilan inferensi dalam ciptaan-ciptaan Bionik.

Paparan selanjutnya dalam makalah ini menyajikan konsep-konsep Bionik, ciptaan-ciptaan Bionik pada makhluk hidup (manusia, hewan dan tumbuhan), serta hubungan penalaran ilmiah dengan ciptaan-ciptaan Bionik (Bionic Invention).

\section{METODE}

Metode penelitian kajian filsafat yang digunkan dalam menulis artikel ini menggunakan bukti teks, yaitu menemukan catatan atau dokumen dahulu untuk memperkuat pemikiran yang ditemukan yang benar-benar dari filosof dikumpulkan secara sistematis dari pemikiran para ahli.

\section{HASIL DAN PEMBAHASAN}

\section{Definisi Bionik}

Pengenalan kata bionik (bionic) pertama kali diperkenalkan oleh Jack E. Steele saat bekerja pada Aeronautics Division House di Wright-Patterson Air Force Base, Dayton, Ohio, pada tahun 1958. Besar kemungkinan, Jack E. Steele terinspirasi dari bahasa Yunani (bi-on atau dilafalkan "bee on") yang artinya hidup, dan -ic yang berarti "seperti". Jadi, jika dipadukan menjadi "seperti hidup". Adapun secara etimologi, bionik didapat dari perpaduan dua kata, yaitu "Bio" dari Biologi, dan "nik" dari elektronik (Juan, 2014).

Bionik adalah sebuah istilah yang mengacu kepada aliran gagasan dari biologi sampai teknik dan sebaliknya (Juan, 2014). Bionik adalah ilmu yang digunakan untuk mengganti struktur anatomik atau proses fisiologi dengan komponen elektronik atau mekanik (Arnot, 2009). Ilmu bionik ini sedang mengalami kemajuan besar, misalnya pengembangan telinga bionik, mata buatan, dan prostesis sensoris. Konsep bionik ini pertama kali dimasyarakatkan pada tahun 1970an melalu media televisi, dan dimasa itu hal tersebut termasuk fiksi ilmiah, akan tetapi kemajuan teknologi dan bersatunya disiplin ilmu seperti elektronika dan biologi telah menjadikan bionik suatu kemungkinan yang sungguhsungguh nyata (Arnot, 2009). Dengan menggunakan reseptor silikon untuk secara langsung menghubungkan alat buatan dengan saraf (Arnot, 2009). Ide yang inovatif bionik ini berasal dari banyak bidang, Mulai dari biologi, fisika dan kimia hingga teknik material. Ciptaan berdasarkan alam ini kemudian diterapkan lebih banyak bidang lagi, khususnya arsitektur, disain, dan produksi (Fell and Pearson, 2007). Selain itu, Bionik merupakan sebuah teknologi yang digunakan dalam dunia kedokteran dalam mengganti anggota tubuh yang sudah rusak atau bahkan menambahkan bagian tubuh ke orang atau hewan yang cacat fisik, contohnya; mata, kaki, telinga dan bahkan otak pun bisa 
di ganti.

Di bidang kedokteran, Bionika berarti pergantian atau perbaikan organ-organ atau bagian tubuh lainnya oleh versi-versi mekanis (prosthesis). Penanaman bionik berbeda dengan bagian badan buatan belaka dengan meniru fungsi aslinya dengan sangat persis, atau bahkan mengunggulinya. Landasan utamanya ialah fisika dikombinasikan dengan biologi (fisiologi) dan psikologi. Dengan pengetahuan tersebut kita bisa mengaplikasikan atau implementasikan dalam banyak persoalan. Salah satu aplikasi (implementasi) teori bionika adalah, misalnya, dalam penyembuhan. Penyembuhan ini dinamakan penyembuhan bionik (bionic recovery) (Arnot, 2009).

\section{Penalaran Ilmiah}

Metode berfikir ilmiah dapat dilakukan melalui tiga jenis penalaran, yaitu Penalaran Deduktif, Penalaran Induktif, dan Penalaran Abduktif (Redja, 2001). Untuk memperoleh pengetahuan, maka digunakanlah metode berfikir ilmiah (Sumadi, 2010). Terdapat tiga jenis penarikan kesimpulan dalam metode berpikir ilmiah, yakni berdasarkan inferensi induktif, inferensi deduktif dan inferensi abduktif (Kuhn, 2000). Penalaran ilmiah atau scientific reasoning merupakan kemampuan seseorang untuk mengetahui alasan-alasan yang mendukung atau melawan putusan-putusan yang dibuat berdasarkan situasi dan fakta-fakta yang relevan. Indikator ini berhubungan langsung dengan kemampuan menganalisis seseorang, seseorang yang mampu memberikan alasan yang tepat dalam menjawab sebuah pertanyaan dapat dipastikan memiliki kemampuan menganalisi yang tinggi. Manusia berpikir untuk menemukan pemahaman atau pengertian, pembentukan pendapat, dan kesimpulan atau keputusan dari sesuatu yang dikehendaki (Achmadi, 1998). Menurut Himsworth (1997), manusia adalah makhluk yang berpikir. Setiap saat dari hidupnya, sejak dia lahir sampai masuk lianglahat, dia tak pernah berhenti berpikir. Hampir tak ada masalah yang menyangkut dengan perikehidupan yang terlepas dari jangkauan pikirannya, dari soal paling remeh sampai soal paling asasi (Hardiman, 2004).

\section{Ciptaan-ciptaan Bionik}

Berikut ini ciptaan-ciptaan Bionik pada manusia, hewan, dan tumbuhan, baik sebagai media dan inspirasi penciptaan (National Geographic edisi Januari 2010).

\section{Manusia Bionik}

\section{a. Mata bionik}

Mata Bionik untuk penderita Retinitis pigmentosa merupakan terobosan teknologi yang canggih untuk bisa membantu pasien penyakit ini memperbaiki penglihatannya. Ini merupakan penyakit keturunan yang menyebabkan pasien sepenuh buta sebelum usia 40 tahun. Walaupun teknologi ini tidak membuat pasien bisa mendapat penglihatan yang utuh tetapi mereka dapat mendeteksi cahaya dan gelap termasuk untuk mengindentifikasi lokasi atau pergerakan objek dan manusia. Suatu elektroda diimplantansi dengan proses bedah dan kemudian di kombinasikan ke kacamata yang menggunakan video camera. Kacamata ini memproses semua data visual dimana video direkap dan dikirim melalui sinyal yang akan diproses ke otak. Pada sekitar tahun 1997, dua orang penyelidik yaitu Profesor Greg Suaning dan Profesor Nigel Lovell telah membuat sebuah organ penglihatan tiruan yang bertujuan mengubati penyakit yang menyebabkan hilang daya penglihatan atau buta. Pada asalnya projek ini dijalankan di Universiti New South Wales (UNSW) dari unit Kejuruteraan Bioperubatan, tetapi pada tahun 2002, Dr Suaning telah berpindah ke Universiti Newcastle (UNEW). Pada ujung tahun 2007 Profesor Greg Suaning dan Profesor Nigel Lovell kembali ke UNSW sebagai Profesor Bersekutu. Satu pasukan penyelidik yang berdedikasi bekerjasama dalam projek ini bersama-sama wakil dari Pusat Penyelidikan Mata Australia (CERA) dari Universiti Melbourne, Institut Telinga Bionik (BEI) serta Vision Sciences Group dari Australian National University (Jessy Dorn, 2009). 


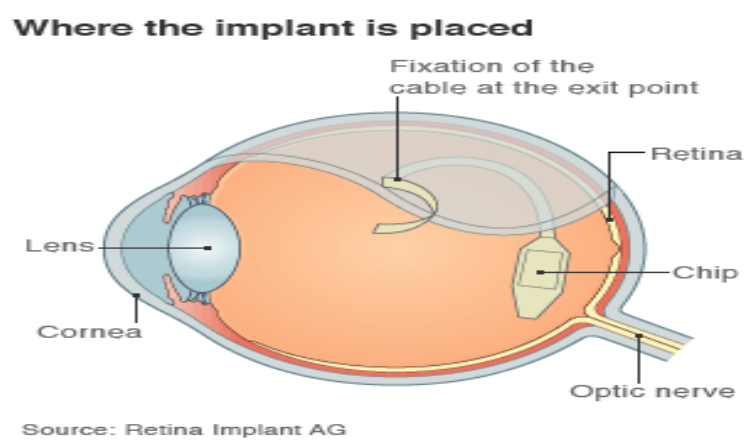

Gambar 1. Mata Bionik

\section{b. Tangan Bionik yang Bisa Bergerak dan Merasakan}

Salah satu kemajuan dunia robotika yang sangat dinantikan adalah penggabungan komponen robot dengan manusia. Dengan alat ini manusia mampu bergerak atau melakukan aktivitas dengan baik. Bahkan bisa merasakan sesuatu yang telah hilang dari badannya. Teknologi sejenis ini sedang dikembangkan oleh ilmuwan. Ilmuwan mengembangkan sebuah alat yang mampu bergerak sesuai sensor dari saraf dan otot. Saat kita ingin menggerakkan benda ini, maka secara otomatis alat bernama myoelectric meresponsnya. Pada tahun 2006, Todd Kuiken membuat penemuan Bionik dari sebuah kasus kecelakaan, yaitu tangan Bonik. Todd Kuiken menyatakan saraf-saraf di ujung anggota tubuh yang diamputasi tetap dapat mengirim sinyalsinyal ke otak.

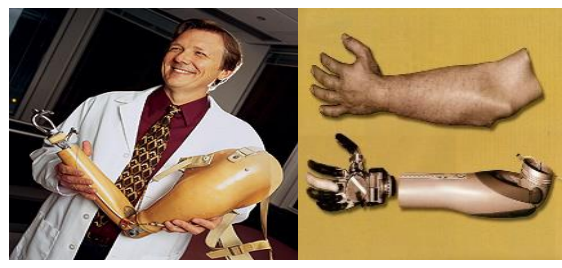

Gambar 2. Tangan Bionik

\section{c. Kaki Bionik}

Letnan Kolonel Greg Gadson yang menjadi korban ledakan bom pada tahun 2007 dan harus kehilangan kedua kakinya, kini dengan kemajuan bionik, ia mampu berjalan kembali (Michael Goldfarb, profesor teknik mesin dari Vanderbilt, 23 Agustus 2011). Kaki palsu Vanderbilt dirancang untuk kehidupan sehari-hari. Ini membuatnya secara substansial lebih mudah bagi pasien amputasi untuk berjalan, duduk, berdiri, dan naik turun tangga dan berjalan di tempat landai. Penelitian telah menunjukkan bahwa pengguna yang dilengkapi dengan perangkat ini secara alami berjalan 25 persen lebih cepat pada permukaan bertingkat daripada ketika mereka menggunakan kaki palsu biasa. Itu karena mereka membutuhkan energi 30 sampai 40 persen lebih rendah.

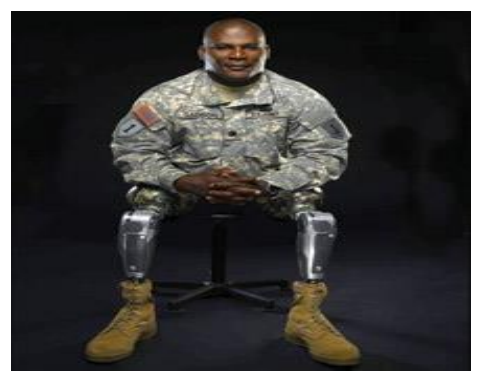

Gambar 3. Kaki Bionik

\section{d. Telinga (Rumah siput) Bionik}

Telinga bionik disebut juga implan koklear (Arnot, 2009). Alat pendengaran yang letaknya dalam 
dan mengandung reseptor khusus yang disebut sel rambut (koklea). Sel ini beraksi terhadap gelombang bunyi dengan bergetar sehingga dapat mengantarkan impluls listrik keserabut saraf auditorius (Arnot, 2009). Pada beberapa bentuk ketulian, sel rambut tidak berfungsi, kemudian telinga bionik ini diciptakan dengan nama implan koklear yang terdiri atas elektrode yang kecilkecil, jumlahnya sampai 22 buah dan diaktifkan oleh berbagai frekuensi serta tinggi nada, yang merangsang serabut saraf auditorius, kemudian gelombang tersebut diterima oleh mikrofon dan pemancar, kemudian dihantarkan ke alat penerima yang tertanam di belakang telinga (Arnot, 2009). Tahun 2009 lalu, Mrs. Tammy Kenny mendapati kenyataan bahwa anaknya Aiden Kenny yang tidak bisa mendengar ternyata tidak bisa dibantu dengan alat bantu dengar biasa. Harapan baru pun datang tatkala pada bulan Februari 2009, ahli bedah di John Hopkins Hopsital memberi bantuan berupa pemasangan kabel tipis dengan 22 elektrode di setiap rumah siput (bagian yang biasanya mendeteksi getaran suara) Aiden. Mikrofon juga dipasang untuk menerima suara dan mengirimkan sinyal ke elektrode yang langsung mengantarkannya ke saraf.

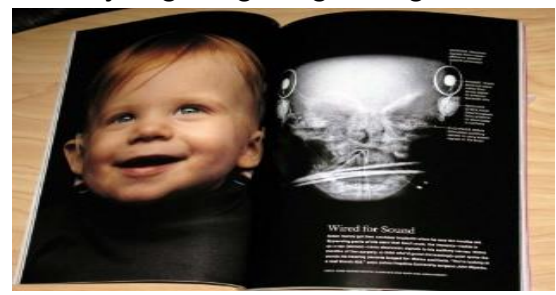

Gambar 4. Telinga Bionik

\section{e. Mata Bionik Jo Ann Lewis}

Retinitis pigmentosa adalah sebuah penyakit degeneratif yang menghancurkan sel pendektesi cahaya di mata (sel kerucut). Ciptaan Bionik oleh Mark Humayun, pakar oftalmologi dari perusahaan Second Sight membuat ciptaan Bionik, yaitu mata bionik. Mengenai mata bionik ini, tidak bisa mengembalikkan pengelihatan hingga 90 persen, karena pada mata bionik (kasus, Jo Ann Lewis, 2006) masih merasa kesulitan untuk menyeberang jalan (Fell, 2007).

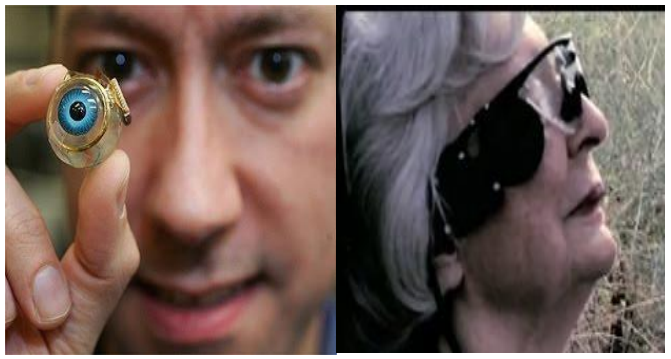

Gambar 5. Mata Bionik

\section{Hewan Bionik}

\section{a. Kucing Bionik}

Sebuah Tim dari Universitas College London dipimpin oleh Profesor Gordon Blunn, mengembangkang penelitian kaki palsu pada seekor kucing. Profesor Blunn dan rekan satu timnya bekerja sama dengan Fitzpatrick untuk mengembangkan implan dengan berat yang seimbang, penggabungan antara tehnik dan biologi. Teknologi seperti ini sebelumnya sudah sangat sering digunakan untuk membuat lengan atau kaki palsu untuk manusia dan tertara korban perang, serta mereka yang kehilangan tangan dan kakinya saat pemboman yang terjadi di London. Seekor kucing yang baru saja di operasi menggunakan teknologi bionik. Tubuhnya yang hitam pekat, bermandikan darah segar yang mengucur deras. Bagian bawah dua kaki belakangnya, tertebas oleh kendaraan pemotong jagung yang lewat. Kucing Oscar baru sebagai kucing bionik pertama di dunia. Kucing ini sekarang telah memiliki sepasang kaki bionik setelah operasi yang terhadapnya berhasil dilakukan. Ini merupakan operasi implan kaki kucing pertama yang dilakukan di dunia. Operasi ini dilakukan oleh Surrey Vet Noel Fitzpatrick (2004). 


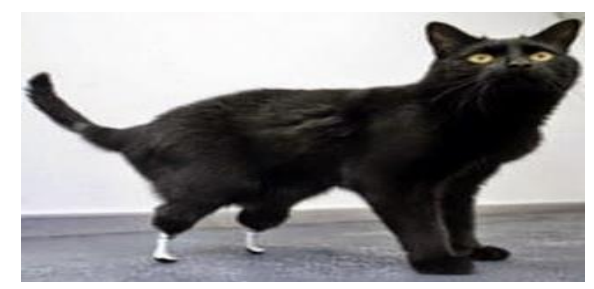

Gambar 6. Kucing Bionik

\section{b. Sebuah Lengan Robot Seperti Belalai Gajah}

Robotika selalu terikat oleh keterbatasan komputer, tetapi karena teknologi komputer terus berkembang, perhitungan yang lebih kompleks untuk berbagai gerakan yang lebih luas menjadi mungkin. Kemampuan yang fleksibel, gerakan lembut telah memberikan cara untuk desain yang lebih maju seperti yang satu ini, sistem penanganan 'biomechatronic' baru yang didasarkan pada belalai gajah. Dibuat oleh Festo perusahaan teknik Jerman, robot ini mampu mengangakat beban berat secara halus dengan menggembungkan atau mengempiskan kantung-kantung udara dalam setiap 'tulang belakang'.

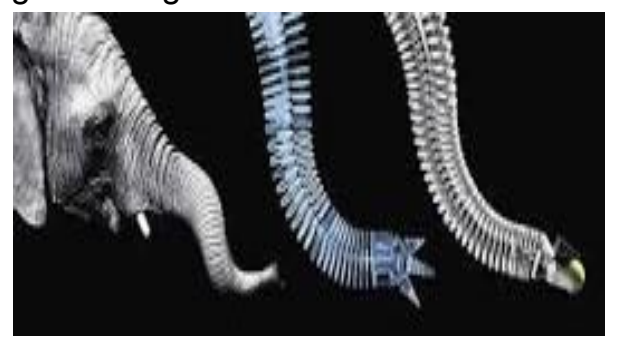

Gambar 7. Tangan Robot Bionik

\section{c. Perekat Terinspirasi Dari Tokek}

Sejumlah peneliti dari Universitas Massachusetts, Amherst, telah mengembangkan Geckskin, sebuah perekat dengan kemampuan daya rekat yang kuat. Perekat ini bisa menggantikan jahitan dan staples di rumah sakit. Dengan penemuan ini, ide untuk memiliki kemampuan untuk dapat memanjat di dinding vertikal seperti spiderman mungkin dapat terwujud. Mark Cutkosky, seorang profesor teknik mesin di Universitas Stanford, mengembangkan 'Stickybot' dengan perekat kering jenis yang sama memungkinkan mereka melekat pada permukaan yang paling mustahil. Ini 'perekat arah' bergantung pada jutaan bulu pada punggung kaki tokek. Perekat lain semacam iniseperti berjalan-jalan dengan permen karet pada kaki anda, anda harus menekan ke permukaan dan kemudian anda harus bekerja untuk menariknya keluar. Tapi dengan adhesi terarah, hampir seperti anda dapat semacam kail dan diri anda melepas kaitan dari permukaan (Cutkosky, 2000).

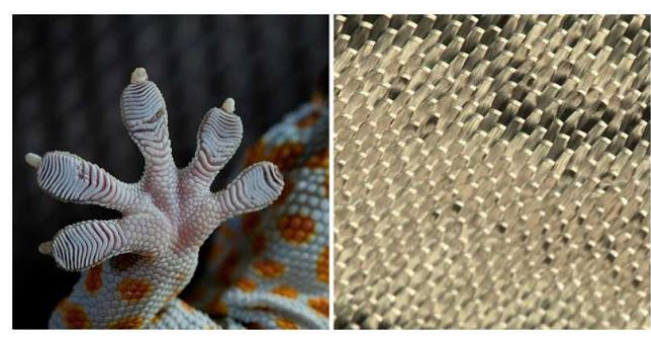

Gambar 8. Perekat Bionik

\section{d. Teknologi Sonar dan Peringatan Tsunami Dari Kebiasaan Lumba-Lumba}

Tenggelamnya kapal Titanic di tahun 1912 adalah tragedi yang membuat umat manusia sangat terdorong untuk mengembangkan teknologi yang mampu mendeteksi sesuatu yang berada di bawah air. Sampai pada akhirnya di tahun 1915 seorang fisikawan asal Perancis bernama Paul Langevin menemukan sebuah sistem yang didesain untuk mendeteksi objek di bawah air 
menggunakan bantuan gelombang suara dan gema yang dihasilkannya. Hal tersebut kini diketahui sebagai SONAR.

Meski teknologi ini memang baru bagi manusia, beberapa hewan sebenarnya sudah menggunakan gelombang suara untuk navigasi, berburu dan mencari mangsa. Kelelawar dan lumba-lumba adalah beberapa di antaranya. Hal yang mereka lakukan adalah memancarkan gelombang suara, lalu mereka menggunakan gema yang muncul untuk mendeteksi lokasi obyek yang berada di sana.

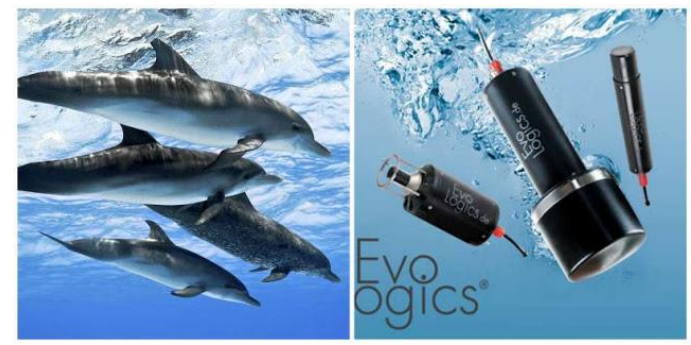

Gambar 9. Bionik Sonar dan Peringatan Tsunami Dari Kebiasaan Lumba-Lumba

\section{e. Teknologi LED Terinspirasi dari Kunang-Kunang}

Lampu merupakan salah satu penemuan terbesar yang telah merubah dunia, keberadaan lampu ternyata telah memberikan nuansa baru bagi kehidupan manusia terutama disaat malam tiba. Dengan lampu semua masih bisa dilakukan. Meski sudah ditemukan sejak lama. Ternyata bola lampu masih punya banyak masalah dalam hal efisiensi. Mulai dari Lampu kaca hingga Lampu LED yang sekarang ini sudah menjadi trending masih saja mengalami hambatan. Terutama lampu LED yang dalam prakteknya cahaya masuk sendiri ke dalam bohlam LED. Hal ini mengakibatkan menurunnya efisiensi terangnya lampu dan boros energi. Karena permasalahan tersebutlah, para peneliti dari berbagai negara mencoba berkumpul dan mulai melakukan penelitian serta observasi pada hewan di alam yang bisa menghasilkan cahaya. Seperti yang kita tahu, keistimewaan kunang-kunang tersebut adalah bisa mengeluarkan cahaya terang di malam hari.

Melalui penelitian itulah para peneliti menemukan jika lampu di tubuh kunang-kunang memiliki exosketeleton yang bergerigi dengan sisik yang menonjol, serta sebuah permukaan miring di dalamnya. Hal ini yang mencegah refleksi ke dalam dari lampu dan membuat semua cahaya lampu di tubuh kunang-kunang mengarah keluar. Hal ini diaplikasikan oleh seorang ilmuwan bernama Nicolas Andre dari University of Sherbrooke di Kanada, dengan menggunakan laser untuk membuat tekstur serupa dari LED. Hal ini ternyata berhasil dan membuat lampu LED jadi 1,5 kali lebih terang ketimbang sebelumnya, dengan energi yang sama.

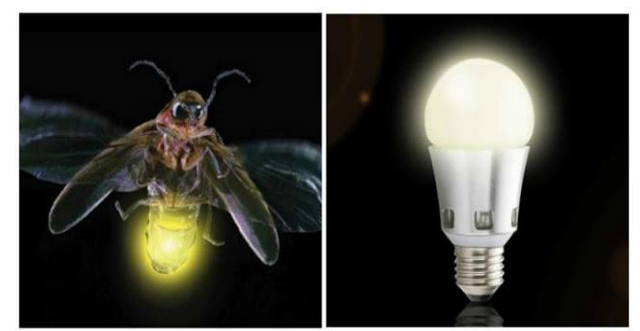

Gambar 10. Bionik Teknologi LED Terinspirasi dari Kunang-Kunang

\section{Tumbuhan Bionik}

\section{a. Tanaman Bionik}

Michael Strano, seorang profesor sekaligus pemimpin Tim peneliti proyek pada tahun 2013, mengatakan bahwa dengan penanaman unsur nano material pada tubuh tanaman mampu membuat tanaman menjadi lebih tahan terhadap perubahan lingkungan, meningkatkan adaptasi tanaman pada lingkungan berbeda, dan yang terpenting adalah setiap tanaman rekayasa 
mampu menyediakan sumber daya dan distribusi air secara mandiri. Menurut Strano dan Juan Pablo Giraldo, seorang ilmuwan biologi, penemuan ini betul-betul menghasilkan potensi yang "gila" karena di masa depan, tanaman mungkin dapat dikembangkan lebih lanjut sebagai perangkat fotonik yang mampu mendeteksi tidak hanya polusi udara namun juga kehadiran dari unsur-unsur bahan peledak dan senjata kimia.

Ide awal proyek tanaman bionik ini berasal dari pemikiran bahwa sel surya mandiri dapat dibuat dari sel tumbuhan. Sel surya mandiri maksudnya sel surya yang dapat memperbaiki dirinya sendiri dan kemampuan memperbaiki diri sendiri hanya dapat dilakukan oleh makhluk hidup (sel hidup) (Juan, et al, 2014).

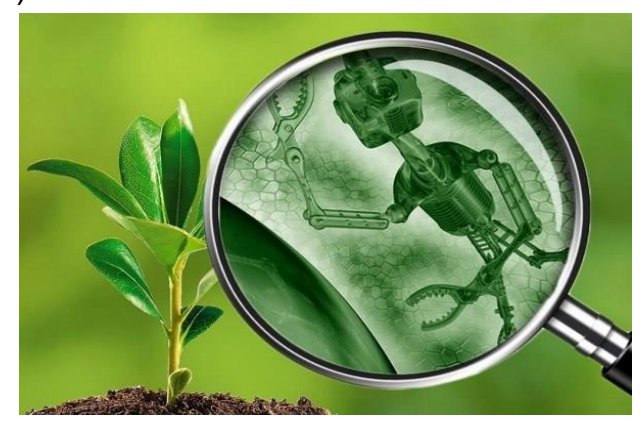

Gambar 12. Daun Bionik

\section{b. Daun Bionik (Bionic Leaf)}

Hal yang istimewa ditunjukkan oleh para peneliti dari Universitas Harvard pada tahun 2014, telah berhasil menciptakan daun Bionik dengan kemampuan yang sangat pintar yaitu daun yang diberi nama Bionic Leaf 2.0. Daun ini bisa mengubah Hidrogen menjadi bahan bakar minyak dengan menggunakan tenaga matahari sebagai sumber utama. Proyek Bionic Leaf 2.0 dipimpin oleh Daniel Nocera dan Pamela Silver pada tahun 2014 yang merupakan profesor di bidang biochemistry dan sistem biologi di Harvard Medical School. Dalam penelitian ini Daniel Nocera menggunakan katalis berupa campuran cobalt dan fosfor. Katalis ini dikatakan mampu mengkonversi cahaya matahari yang diterima menjadi biomassa dengan tingkat efisiensi 10 persen dan angka efisiensi itu lebih tinggi 10 kali lipat dibandingkan dengan yang terjadi secara alami di alam. Proyek Bionic Leaf ini sendiri merupakan kelanjutan dari proyek yang sempat dikerjakan pada tahun 2013. Bionic Leaf 2.0 memiliki kemampuan yang lebih efisien ketimbang proses fotosintesis daun biasa secara alami (Liu C, 2014).

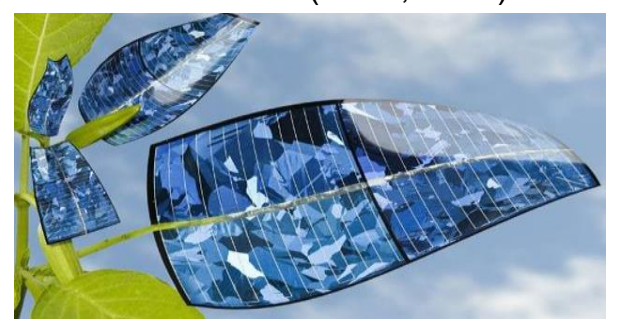

Gambar 11. Daun Bionik

\section{c. Penggunaan Velcro Terinspirasi dari Tanaman Burdock}

Menjadi perekat serbaguna yang biasa diletakkan ditas atau dompet, Velcro adalah salah satu penemuan yang cukup berguna. Ternyata Velcro ditemukan oleh insinyur asal Swiss bernama George de Mestral, yang secara tak sengaja 'ketempelan' duri dari tanaman burdock. Duri ini banyak menempel di celana dan tubuh anjingnya. Sang insinyur menemukan bahwa sebuah pengait kecil yang ada di biji dan duri dari tanaman burdock bisa menempel ke benda bersimpul, seperti serat pakaian. Sang insinyur akhirnya bereksperimen selama satu dekade sampai akhirnya menemukan "resleting yang tak ber-resleting" yang saat ini dikenal sebagai Velcro. 


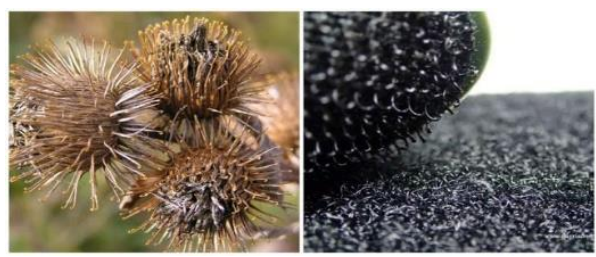

Gambar 13. Velcro Terinspirasi dari Tanaman Burdock

\section{d. Hubungan Penalaran Ilmiah dengan Ciptaan-ciptaan Bionik}

Ciptaan-ciptaan Bionik (Bionic Inventions) bisa dikategorikan ke dalam penalaran induktif, deduktif dan abduktif dapat diuraikan sebagai berikut:

1) Bionic Inventions suatu kasus-kasus yang khusus menuju suatu kesimpulan umum (generalisasi) yang terjadi yaitu suatu inferensi yang bersifat induktif yang dikenal sebagai logika informal atau argument sehari-hari yang dapat ditemukan pada Bionic Inventions: manusia bionik, hewan bionik dan tumbuhan bionik.

2) Bionic Inventions yang dilakukan oleh manusia yaitu suatu inferensi yang bersifat deduktif yang melandasi konstruksi/formulasi hipotesis dari suatu teori silogisme logika formal). Penalaran deduktif terdapat pada Bionic Inventions: manusia bionik, hewan bionik dan tumbuhan bionik.

3) Bionic Inventions dapat dikatakan sebagian besar dikategorikan kedalam inferensi abduktif dengan alasan sebagai berikut: a). Abduktif menghasilkan suatu proposisi yang mengandung konsep universal (generalitas). Kesimpulan dari proses itu adalah suatu proposisi yang menempatkan suatu kasus khusus tertentu dalam suatu kelas atau kelompok. Sebagai contoh dalam ciptaan Bionik pada manusia, yang bisa digunakan untuk semua orang tanpa dibatasi oleh umur, gender, RAS dan lain-lain. b). Abduktif seorang ilmuan akan menggunakan instingnya untuk membuat suatu pilihan yang ekonomis dan berguna ketika menghadapi begitu banyak penjelasan yang harus diuji. ciptaan Bionik ini dibuat menggunakan bahan yang lebih ekonomis, artinya mempunyai nilai guna untuk seluruh makhluk hidup yang ada disekitar lingkungannya. c). Proses abduktif menegaskan bahwa ilmu pengetahuan selalu berusaha untuk menangkap orisinalitas realitas. Ciptaan Bionik harus sesuai dengan kenyataan yang ada. Misalnya, sekarang ini mata Bionik dengan estetika sesuai dengan kemauan individu. d) Abduktif yang berhasil mengandaikan keterlibatan yang menyeluruh dan imajinasi yang bebas. Ciptaan Bionik akan selalu berkembang mengikuti perkembangan teknologi atau kekinian (yang dulu manual sekarang dengan kecanggihan).

\section{PENUTUP}

\section{Simpulan}

Berdasarkan pemaparan makalah tentang penalaran ilmiah dalam ciptaan-ciptaan Bionik (Bionic Invention) di atas, maka dapat disimpulkan bahwa penemuan-penemuan Bionik dikategorikan ke dalam penalaran Induktif, Deduktif dan Abduktif. Ciptaan-ciptaan Bionik (Bionic Invention) merupakan inovatif masyarakat saat ini sebagai sistem perkembangan ilmu pengetahuan serta eksploitasi pemikiran yang tiada henti. Sebuah sistem yang dimaksud adalah sistem di mana manusia akan terus mengejar informasi demi mendapatkan tujuan yang mereka inginkan dengan bantuan teknologi. Perkembangan teknologi menjadi sebuah daya jual yang memiliki nilai tiadatara. Jadi bukan hal yang aneh jika berbagai lembaga penelitian mulai memanfaatkan hal tersebut untuk kebutuhan mereka. Selanjutnya, perlu adanya kewaspadaan dalam upaya eksploitasi serta hasrat libido yang dimiliki oleh teknologi itu sendiri. Pada akhirnya, pemegang kekuasaan di bidang teknologi maupun masyarakat dikuasai oleh hasrat libido dalam penggunaan dan pengembangan sebuah teknologi. Bidang medis pun memiliki upayaupaya untuk mengatasi batas-batas umur manusia dengan menciptakan berbagai produk organ Bionik 
yang memiliki fungsi layaknya organ asli manusia. Bionik meskipun hal tersebut tentu merupakan sebuah hal positif, namun manusia tidak akan tahu pada akhirnya apa yang disebut sebagai kecerdasan buatan tersebut akan tetap 'berpihak' atau menurut pada manusia atau sebaliknya dan ingatlah bahwa Seluruh aktivitas hidup manusia harus diarahkan untuk beribadah kepada Allah SWT sebagai pencipta semua makhluk. Dalam cerita pendek Runaround (1942), Isaac Asimov menjawab dengan tiga aturan ciptaan-ciptaan Bionik (Bionic Invention). Pertama, ciptaan-ciptaan Bionik (Bionic Invention) tak boleh mencelakakan manusia. Kedua, ciptaan-ciptaan Bionik (Bionic Invention) menaati perintah manusia kecuali berlawanan dengan aturan pertama. Ketiga, ciptaan-ciptaan Bionik (Bionic Invention) menjaga eksistensinya tanpa menentang aturan pertama dan kedua.

\section{Saran}

Penulis memberikan saran melalui artikel ini, hendaknya melakukan penelitian dalm bidang peningkatan dan pengembangan pada kemajuan teknologi dan berkembangnya pikiran manusia yang jauh lebih siap dari sebelumnya dapat berinovasi pada ciptaan-ciptaan bionik (bionic inventions).

\section{DAFTAR PUSTAKA}

Arnot, David. 2009. Pustaka kesehatan Populer Mengenal Berbagai Macam Penyakit infeksi, volume 9. Jakarta: PT Bhuana Ilmu Populer. p. 104.

Beaty, Erin. 2012. Effects of perspective and belief on analytic reasoning in a scientific reasoning task. Journal Thinking \& Reasoning, 18 (4), 441-460

http://dx.doi.org/10.1080/13546783.2012.687892.

Fell, C.; Pearson, F. (November 2007). "Historical Perspectives of Thoracic Anatomy". Thoracic Surgery Clinics 17 (4): 443-8.

Doi:10.1016/j.thorsurg.2006.12.001.

Glickman, Rosalene. 2002 Optimal Thinking. New York: John Wiley \& Sons, Inc.

Juan P. Giraldo, Markita P. Landry, Sean M. Faltermeier, dkk. 2014. Plant nanobionics approach to augment photosynthesis and biochemical sensing. Nature Materials.

Kuhn, D., \& Udell, W. 2000. The development of argument skills. Child Development, 74(5), 1245-1260.

Kuhn, D. 2001. How do people know? Psychological Science, 12(1), 1-8.

Laius, Anne. 2011. Impact on student change in scientific creativity and socioscientific reasoning skills from teacher collaboration and gains from professional in service. Journal of Baltic Science Education, Vol. 10, No. 2, (P. 127-137), ISSN 1648-3898.

Lawson, A. E. 2000. Classroom test of scientific reasoning. Retrieved 01 Jan. 2008. http://www.public.asu.edu/ anton1/LawsonAssessments.htm.

Liu. C, B. C. Colon, M. Ziesack, P. A. Silver, D. G. Nocera. Pemisahan air-biosintesis sistem dengan efisiensi pengurangan CO2 melebihi fotosintesis. Sains, 2016; 352 (6290): 1210 DOI: 101126.

National Geographic. Manusia Bionic. Edisi Januari 2010

Pusat Bahasa (2005). Kamus Besar Bahasa Indonesia Edisi Ketiga. Jakarta: Balai Pustaka. ISBN 9789794071823)

Suriasumantri, J.S. 2009. Fisafat IImu: Sebuah Pengantar Popular. Jakarta Pustaka Sinar Harapan 
Tawil. M, Liliasari. 2013. Berpikir Kompleks dan Implementasinya dalam Pembelajaran IPA. Makassar: Universitas Negeri Makassar Press. 